\title{
Farm economic evaluation of elderberry production
}

\author{
Apáti, F. \\ University of Debrecen, Faculty of Economics and Business, Institute of Management Sciences \\ H-4032 Debrecen, Böszörményi Street 138.; e-mail: fapati@agr.unideb.hu
}

\begin{abstract}
Summary: In this present study the efficiency as well as the farm economic advantages and disadvantages of elderberry production are examined. Our objective is to determine the fact that under what conditions the elderberry production may be profitable regarding the present economic and market situations. Our analysis was carried out by a simulation model based on a farm-level data gathering in production enterprises. The total investment cost of an up-to-date, elderberry orchard of traditionally cultivated without irrigation is between 1000 to 1700 thousand HUF per one hectare and turning to productivity is expected within $4-5^{\text {th }}$ years. These orchards are able to produce yields of 8,0 to 9,0 tons per one hectare in the average of the productive years, which makes reaching a revenue of 800 to 1000 thousand HUF possible regarding a per kg average selling price of 80 to 110 HUF. By this a net profit of 200 to 400 thousand HUF may be realized in case of a per hectare production cost of 600 to 700 thousand HUF. At the end of the lifetime of the orchard (12-15 ${ }^{\text {th }}$ year) an internal rate of return of 10 to $14 \%$, an NPV of 1500 to 2000 thousand HUF per one hectare are typical in an average case, and the payback may be expected in the $6^{\text {th }}$ to $8^{\text {th }}$ year. From the farm economic aspect the elderberry may be considered as an extensive sector, which advantages are low capital and labour need, early recovery, good-acceptable profit on capital and cost to profit ratios, but its disadvantage is low per hectare profit comparing to intensive fruit species and orchards. In this way in general farms of capital-extensive and avoiding risks choose elderberry production.
\end{abstract}

Keywords: elderberry, elderberry production, farm economic analysis, elderberry economics

\section{Introduction}

The elderberry production in Hungary started at the second half of the 1990'ies. Its development accelerated at the turn of the millennium, by the years 2006 to 2007 the growing area reached 2500 hectares. Its rate of development ceased this time; however, as after the extremely favourable selling prices at the beginning, the market collapsed, the price did not make even maintaining the profit to a minimum level possible. After the year 2010, because the selling prices turned to favourable again, further tendencies for the establishment occurred, thus today an orchard surface of 4500 hectares may be found in Hungary. It must be noted that the extreme wet weather of the year 2010 contributed to the normalization of the market conditions as well, because of this due to the permanent inland pressure several orchard surface was damaged or significantly suffered from thinning, which reduced the basis of production by 20 to $40 \%$.

According to Csizmadia (2011) additionally 1000 to 1500 hectares orchard may be established in the country, as besides the present production of 8 to 10 thousand tons, further quantity of 10 to 12 thousand tons may be sold. This reason is the fact that the demand for food colorings of natural-based has been increasing all over Europe.

The typical cultivation system of elderberry is trunkstem crown, but the natural rounded broad crown is used more and more frequently. The very heterogenic standard of the national elderberry production may be characterized by yields of 8 to 10 tons per hectare in farms of high standard besides the national average yield of 2 to 3 tons per hectare. In the most up-to-date farms in good years yields of even 13 to 15 tons per hectare may be realized in case of irrigation and using fertigation. Its cultivation is relatively simple, its inputs are low, and it does not have any significant production risk if the production site has been chosen properly.

\section{Objectives}

The main objective of this present study is to determine the fact that what cost and profit relations are typical to elderberry production, and under what conditions it may be profitable if it is characterized by a traditional cultivation, a high technological standard without irrigation, which constitutes most of our orchards yet. The specific objectives relating to this are the followings:

- investigation of inputs and production cost during the establishment and in the productive period,

- determination of yield, selling price and production value,

- evaluation of profit generation, profitability and efficiency,

- characterization of recovery calculations on the whole lifetime of the orchard,

- determination of the major conditions of profitable elderberry production by carrying out sensitivity analysis of all these factors.

On these bases, the most important advantages and disadvantages of elderberry production are identified, 
which may contribute to making good decisions for the establishment and production.

\section{Materials and methods}

The economic issues of elderberry orchards in good conditions, in a traditionally cultivated system cultivated on a high standard are examined in this study. The parameters of the characterized orchard types are the following:

- trunk-stem crown form

- distance between rows is 5.0 meters, distance within a row is 3.0 meters (666 stems per one hectare)

- the 'Haschberg' is the only one cultivar in the cultivar structure,

- there is not any irrigation and support system,

- the technology of harvesting is carried out by hand in one or two courses,

- the reachable yield level in good years is 10 to 12 tons per one hectare, in the average of the productive years it is 8 to 9 tons per one hectare,

- the sold products are fruits in plastic bins, immediately sold after harvesting without post-harvest operations (cost of storage, selection and packaging do not arise).

Such an orchard may be characterized by yields exceeding the national average, good product quality (size, ripeness), high inputs, production technology of good standard and strict technological discipline. It must be highlighted that these parameters reflect not the Hungarian average but the best orchards belonging to the upper third. The prices of the utilized inputs (materials, labour, mechanical work) and the prime cost reflect a price standard in 2012-2013 years. The price of materials lacks the VAT, while the wages of labour is considered altogether with benefits. The time wage was 700 HUF per hour, and it was calculated to every labour hour regardless the fact that whether paid or unpaid family labour worked. The selling prices are represented by a longer-term (3 to 5 years) average. Data gathering basing the analysis happened in production enterprises.

In case of the examined model (orchard) good production standard and strict technological discipline were set, thus the calculation refers not to the national average but to up-todate farms producing on good standard, which take up of 30 to $40 \%$ of the 4.500 hectares elderberry orchard.

The utilized analysing methods are cost-benefit analysis and investment analysis on return. In the latter case the dynamic methods were chosen as they give a more valid and precise results from the professional aspects. They differ from static methods in the fact that they count with the time value of the money (Illés, 2002). There are several indicators for dynamic investment analysis, from which NPV (Net Present Value), DPP (Discounted Payback Period), IRR (Internal Rate of Return, return on capital) are calculated (Flock, 2000; Brealey, 2006). The return on capital of alternative investment is reflected by the calculative interest rate, which value is $6 \%$, being the interest need of the investment capital.

\section{Results}

\section{Investment costs}

An elderberry orchard cultivated in a traditional way does not need any support system, and even irrigation is not typical in most of the orchards. The costs of the stock and planting, as well as of soil preparation constitute the two major items of the establishment costs. Comparing to other fruit species, the establishment cost is very low, it is only 1000 to 1700 thousand HUF per one hectare thank to the low number of plants, to the relatively cheap propagating material and the dispensable support system (Table 1).

Table 1: The Investment Cost of the Characterized Elderberry Orchard

\begin{tabular}{|l|c|c|}
\hline \multirow{2}{*}{ Denomination } & \multicolumn{2}{c|}{ Cost (thousand HUF/ha) } \\
\cline { 2 - 3 } & In an interval & In average \\
\hline Site and soil preparation & $400-800$ & 600 \\
\hline Establishing the support equipment & 0 & 0 \\
\hline Stock and planting & $400-550$ & 480 \\
\hline Establishing irrigation system & 0 & 0 \\
\hline Other & $200-350$ & 270 \\
\hline Total establishing costs & $1.000-1.700$ & 1.350 \\
\hline $\begin{array}{l}\text { Cultivation cost in the period of } \\
\text { turning to productivity (3 years) }\end{array}$ & $700-1.000$ & 850 \\
\hline Total investment cost & $1.700-2.700$ & 2.200 \\
\hline $\begin{array}{l}\text { Revenue in the period of turning to } \\
\text { productivity (3 years) }\end{array}$ & $400-700$ & 550 \\
\hline Clear investment cost & $1.300-2.000$ & 1.650 \\
\hline $\begin{array}{l}\text { Annual depreciation cost in the } \\
\text { period of productivity }\end{array}$ & $110-200$ & 130 \\
\hline
\end{tabular}

Source: own calculation

It must be noted that during the past several years there were water-saving micro-irrigation systems (with drip or micro-spray) established in up-to-date farms which already constitutes the essential part of the technology increasing the establishment cost significantly by 700 to 1100 thousand HUF per one hectare. This is, however, expected to become a profitable and recovering investment during 2 to 4 years because of the higher yields by 25 to $30 \%$, better yield safety, greater size of berries and panicles (lower specific picking cost) as well as better orchard condition (plantation deterioration occurs later). As long-term experiences and data-series are available on orchards which are not irrigated, the economic aspects of these kinds of orchards are examined in this study.

The clear investment cost is 1300 to 2000 thousand HUF per one hectare calculating even the cultivation cost and the reachable revenue of the three-year-period of turning to productivity. This is resulted in a depreciation cost of 110 to 200 thousand HUF projected to 10 to 12 productive years. All in all, elderberry may be classified into fruit varieties of low capital need at the beginning. 


\section{Inputs and Production Cost in the Productive Period}

Table 2 summarizes the production cost of elderberry, which is calculated to several yield levels. This reason is the fact that the yield in the average of many years ranges from 6,5 to 11,0 tons per one hectare even in an orchard of good standard having a developed production technology mainly because of frost, hail and drought damages. Regarding the production cost of elderberry, the following major conclusions may be defined:

- The annual level of the production technological inputs are low thus the orchard may be cultivated with a production cost of 400 thousand HUF per one hectare. With the change of the yields, this per hectare production cost does not change basically, but its per $\mathrm{kg}$ value decrease proportionally.

- The cost of harvest shows an opposite tendency, its value ranges from 10 to $30 \mathrm{HUF} / \mathrm{kg}$ depending on many factors; it is $20 \mathrm{HUF} / \mathrm{kg}$ in average. The picking cost is a variable cost generally, thus the per hectare value changes proportionally with the yield, while the per $\mathrm{kg}$ value ranges only within a very narrow interval.

- Depreciation and overhead cost are fixed costs; the per hectare values are independent from the yields. The per hectare production cost including depreciation and overhead cost hardly changes within the examined yield interval, regarding the fact that in this relevant yield lane, almost every cost item is fixed costs except for the cost of harvesting.

- On the basis of the facts mentioned above the prime cost per one kilogram ranges from 70 to $110 \mathrm{HUF}$ depending on the yields reachable in the average of many years in case of technologies of good standard.

\section{Yield, Production Value, Profit and Profitability in the Productive Years}

The calculation of production value and profit is summarized in Table 3. The selling prices ranged within a wide interval (30 to $200 \mathrm{HUF} / \mathrm{kg}$ ) during the last 10 years. In the average of many years the selling price is $105 \mathrm{HUF} /$ $\mathrm{kg}$. The annual revenue is 700 to 1200 thousand HUF/ hectare depending on the yield level. The realizable revenue is around zero in case of an average yield of 6 to 7 tons per a hectare regarding average selling prices of many years. It means that it is the yield level which shows the turning point of the profitability, though cash flow still reflects a positive value. In case of an average yield of 10 tons per one hectare or higher than that the cost to profit ratio is favourable, it is about 50\%, though it is not excellent in permanent cultures.

Table 3: Revenue, Profit and Profitability of the Elderberry Orchard Cultivated on a Good Standard Relating to the Whole Productive Years, in Case of Different Yield Levels

\begin{tabular}{|l|l|l|l|l|}
\hline \multirow{2}{*}{ Denomination } & \multirow{2}{*}{ Unit } & \multicolumn{3}{c|}{$\begin{array}{c}\text { Yield level (average yield } \\
\text { of many years) }\end{array}$} \\
\cline { 3 - 5 } & & $6,5 \mathrm{t} / \mathrm{ha}$ & $9,0 \mathrm{t} / \mathrm{ha}$ & $11,0 \mathrm{t} / \mathrm{ha}$ \\
\hline Yield & t/ha & 6,5 & 9,0 & 11,0 \\
\hline Average selling price & HUF/kg & 105,0 & 105,0 & 105,0 \\
\hline Total revenue & thousand HUF/ha & 682,5 & 945,0 & $1.155,0$ \\
\hline Direct production cost & thousand HUF/ha & 658,0 & 695,0 & 702,0 \\
\hline Contribution & thousand HUF/ha & 24,5 & 250,0 & 453,0 \\
\hline Overhead cost & thousand HUF/ha & 60,0 & 60,0 & 60,0 \\
\hline Net profit* & thousand HUF/ha & $-35,5$ & 190,0 & 393,0 \\
\hline Cash flow & thousand HUF/ha & 94,5 & 260,0 & 523,0 \\
\hline Profit to cost ratio & $\%$ & $-4,9$ & 25,1 & 51,5 \\
\hline
\end{tabular}

Source: own data gathering and calculation

* profit before taxes

Regarding profit and profitability, in the average of many years the elderberry produces deficit only in an extremely pessimistic case, in the average of good years it reaches or exceeds 50\% profitability. Comparing to other, more intensive fruit varieties and orchards (intensive apple, semi-intensive apricot), it realizes similar parameters with respect to cost to profit ratio, at the same time regarding the absolute profit volume realized on one hectare it lags behind significantly. On the basis of its farm economic parameters, it may be classified into the extensive cultures.

\section{Recovery Conditions of the Investment during the Lifetime of the Orchard}

Due to limitation on length, we strive to summarize only the major results here. In calculating investment recovery indicators, we used a calculative interest 
rate of $6 \%$ as a basis for comparison. According to our results, regardless subsidies for investment (in case of establishment from completely own sources) and direct production subsidies, the payback period of the investment is 6 to 8 years in a realistic case, while it is 11 to 13 years in a pessimistic case, which means that the investment will recover till the end of the lifetime of the orchard. At the end of the lifetime of the orchard $\left(15^{\text {th }}\right.$ year) the realized NPV is 1,5 to 2,0 million HUF per one hectare in a realistic case, the internal rate of return is 10 to $14 \%$ (by this it lags behind the more intensive fruit species). Regarding subsidies for investment and direct production, the payback period shortens to 5 to 7 years, while the value of the NPV improves to 2,6 to 2,8 million HUF per one hectare, and the IRR to 18 to $23 \%$.

\section{Conclusions}

On the basis of the results, the major farm economic advantages and disadvantages of elderberry may be summarized as follows.

The major farm economic advantages of elderberry are:

- low capital need for the establishment at the beginning,

- low input and labour need in the years of productivity,

- relatively low production risk (frost, danger of hail damages, drought, discontinuous yielding etc.) comparing to other fruit species,

- the relatively low profit may be acceptable and it may result in a satisfactory and good profit to cost ratio because of low production costs,

- in case of total yield damage, the realized loss is low, because the level of production technological inputs is low,

- presently good market position, favourable selling opportunities.
The major farm economic disadvantages of elderberry are:

- low per hectare profit, significantly lagging behind the more intensive fruit cultures, by which the elderberry will be suitable for farms operating in an extensive way and taking few risks.

- Good profitably parameters may only be realized if yields reach or exceed 10 tons per one hectare, for which expertise and the inputs detailed above are essential, that is, elderberry cannot be handled as a modest culture.

These farm economic features shows that elderberry has a relatively low capital and input need, small production risk and is a more extensive fruit variety when comparing to other fruit species, which is able to realize a not so high profit, but a favourable profitability in general due to the low production costs.

\section{Acknowledgement}

This research was supported by the European Union and the State of Hungary, co-financed by the European Social Fund in the framework of TÁMOP-4.2.4.A/ 2-11/1-20120001 'National Excellence Program'. The identification of the application is: A2-MZPD-13-0358

\section{References}

Brealey, R. A., Myers, S. C. \& Allen, F. (2006): Corporate Finance. Eight Edition, McGraw-Hill, 84-143. p., 244-272. p.

Flock, C. (2000): Betriebszweigabrechnung in der Landwirtschaft. Verlag Pflug und Feder. Sankt Augustin, 11-158. p.

Illés M. (2002): A beruházások gazdaságossága. [In: Vezetői gazdaságtan.] Szerk.: Illés M. Kossuth Kiadó,115-162. p.

Csizmadia Gy. (2011): Bodza - 800 ezer Ft a bevétel. Haszon. Agrár Magazin, Budapest, 6. p. 